\title{
Interactions between Scots pine, Ips acuminatus (Gyll.) and Ophiostoma brunneo-ciliatum (Math.): estimation of the critical thresholds of attack and inoculation densities and effects on hydraulic properties in the stem
}

\author{
Natacha Guérard ${ }^{\mathrm{a}, \mathrm{b}}$, Erwin Dreyer ${ }^{\mathrm{b}}$ and François Lieutier ${ }^{\mathrm{a}, \mathrm{c}, *}$ \\ a Zoologie Forestière, INRA Orléans, Avenue de la Pomme de Pin, BP 20619, 45166, Ardon Cedex, France \\ ${ }^{b}$ Unité d'Écophysiologie Forestière, INRA Nancy, 54280 Champenoux, France \\ ${ }^{\mathrm{c}}$ Laboratoire de Biologie des Ligneux, Université d’Orléans-la-Source, BP 6759, 45067 Orléans Cedex 2, France
}

(Received 28 April 2000; accepted 10 July 2000)

\begin{abstract}
The aggressiveness towards Scots pine (Pinus sylvestris L.) of the association between a bark beetle (Ips acuminatus Gyll) and an Ophiostomatale fungus (Ophiostoma brunneo-ciliatum Math.) was investigated by estimating experimentally with young trees, the critical threshold of attack or inoculation densities. Records of the relationship between natural attack densities by the beetles and survival of trees in a pine stand yielded a critical attack density threshold of about $900 \mathrm{~m}^{-2}$. Experimental mass inoculations of young pines with the fungus, in a forest stand in Central France, demonstrated a weak pathogenicity of this fungal species towards Scots pine. Inoculation densities varying from 200 to $1000 \mathrm{~m}^{-2}$ were used. Damage in the bark or in the sapwood recorded three months after the inoculations, remained rather limited. The length of the induced reaction zones in the bark was small as compared to those obtained with more aggressive fungi, and did not increase with inoculation density. Damage in the sapwood, estimated either visually from the observed sapwood drying, and from resinosis, remained limited, but increased significantly with the inoculation density. The impairment of hydraulic conductivity of inoculated trunk segments was rather large with, at highest densities, a loss of conductivity estimated to about $60 \%$. Nevertheless, due to the fact that the resistance to water transfer in the trunk is much smaller than in other organs (like roots or needles), this increase probably only had a small impact on water relations at whole tree level. It may be concluded that the association I. acuminatus - O. brunneo-ciliatum displays only a weak aggressiveness towards Scots pine, and that high densities of attacks or inoculations (above $1000 \mathrm{~m}^{-2}$ ) are required in order to reach the critical threshold able to kill trees.
\end{abstract}

Pinus sylvestris / Ips acuminatus / Ophiostoma brunneo-ciliatum / inoculation density / attack density / resistance level / induced reaction zones / phloem / sapwood / water conductivity / bark-beetle

Résumé - Relations Pinus sylvestris L. / Ophiostoma brunneo-ciliatum Math. / Ips acuminatus Gyll. : seuils critiques de densités d'attaques et d'inoculations ; impact d'inoculations massives sur les propriétés hydrauliques des tiges. La sensibilité de pins sylvestres (Pinus sylvestris L.) aux attaques de scolytes (Ips acuminatus) et de leur champignon associé (Ophiostoma brunneociliatum) a été étudiée en estimant les seuils critiques de densité d'attaques et d'inoculations sur de jeunes arbres. La relation entre la densité d'attaques naturelles et la survie des arbres a permis de déterminer un seuil critique de densité d'attaques d'environ $900 \mathrm{~m}^{-2}$.

* Correspondence and reprints

Tel. (33) 02384948 07; Fax. (33) 02384178 79; e-mail: francois.lieutier@univ-orleans.fr 
Des inoculations massives de jeunes pins en forêt (Orléans, France) effectuées avec le champignon O. brunneo-ciliatum, à des densités de points d'inoculation allant de 200 à $1000 \mathrm{~m}^{-2}$ ont confirmé la faible pathogénicité de cette espèce. Les dégâts observés trois mois après inoculation dans le liber et l'aubier étaient modérés même aux plus fortes densités. La longueur des réactions induites dans le liber était faible par rapport à celle qui résultait d'inoculations avec d'autres champignons, et est restée insensible à l'accroissement des densités d'inoculation. Les dégâts dans l'aubier, estimés visuellement (sections d'aubier desséchées et imprégnées de résine) sont restés modérés mais ont néanmoins augmenté significativement avec la densité d'inoculation. La perte de conductivité hydraulique a été sensible dabs les segments de troncs inoculés. Elle pouvait atteindre $60 \%$ en réponse aux plus fortes densités d'inoculation. Toutefois, cette diminution de conductivité locale n'a probablement eu qu'un faible impact sur les relations hydriques à l'échelle de l'arbre entier, du fait de la faiblesse relative des résistances dans les troncs par rapport à d'autres organes comme les aiguilles. L'association I. acuminatus - O. brunneo-ciliatum s'est donc révélée peu pathogène pour le Pin sylvestre, et les densités d'attaques et d'inoculation susceptibles d'entraîner à terme la mort des arbres sont sans doute très élevées par rapport à d'autres associations scolytes-champignons.

Pinus sylvestris / Ips acuminatus / Ophiostoma brunneo-ciliatum / densité d'inoculation / densité d'attaque / niveau de résistance / réaction induite / aubier / liber / conductivité hydraulique / scolyte / champignon associé

\section{INTRODUCTION}

Bark beetles are one of the major threats to coniferous forests. These insects use trees as a substrate during their life cycle. During periods of endemic population levels, bark-beetles restrict their attacks to weakened or dying trees. The rapidity with which they develop, however, helps them reach epidemic population levels as soon as conditions become favourable, i.e., when sufficient substrate is available like after heavy windbreak damage or severe stress episodes that weaken standing trees. The high population levels allow the beetles to extend their attacks to healthy and vigorous trees [3, 18, 29]. Such epidemic gradations, even if they are rather unfrequent, are nevertheless disastrous for forests. For instance, $300000 \mathrm{~m}^{3}$ pines had to be cut down between 1983 and 1986 after attacks by Tomicus piniperda and Ips sexdentatus [25] and the same amount of Spruce were destroyed between 1992 and 1993 in North Eastern France after attacks by Ips typographus. Dendroctonus ponderosae has been responsible for the death of 80 million pine trees between 1979 and 1983 in USA and 4.7 million of $\mathrm{m}^{3}$ of pine per year in the north of America [30].

Trees are able to develop defence reactions that reject or isolate the aggressors [2]. Such defence processes comprise:

- the flow of pre-existing resin promoted by the mechanical disruption of resin ducts due to insect foraging;

- an induced reaction consisting of an active accumulation of secondary metabolites (terpenes, monophenols,...) around the attack point, that limits the progression of the aggressor; in a second step, the build-up of wound tissue isolates the reaction zone from the rest of the tree [7, 23, 32, 37].

Isolated attacks by most bark-beetle species fail on healthy tree, and only mass attacks can result in insect establishment and in death of the attacked trees. Several observations have shown that above a given attack density, the number of killed trees increases rapidly, suggesting the existence of a critical threshold of attack density $[8,28,31,36]$. A dynamic balance between tree defence and attack density has been described, in which the critical threshold of attack density can be used as a quantitative index for tree resistance. Bark-beetles are furthermore frequently bearing phytopathogenic fungi belonging to the group of Ophiostomatales. The bark beetle associated Ophiosomatales display a weak to moderate pathogenicity. Their role in this mutualistic association is probably to amplify the induced reactions of the trees, thus contributing to exhaust their defence ability, and therefore facilitating the establishment of the insect population by decreasing the critical attack density threshold $[7,19,20]$. In contrast, fungal establishment has sometimes been claimed to constitute a prerequisite for successful beetle establishment in pine [33] and in spruce [13].

It is possible to experimentally estimate this critical threshold of attack density by promoting controlled and variable numbers of insect attacks [31]. A much simpler procedure is to inoculate directly the associated fungus into the bark, with increasing densities of inoculation points, and to detect the density above which damage and possibly tree death can be observed $[6,17]$. It has been shown that the two procedures yield comparable values of density, thus allowing a comparison of critical thresholds for a variety of tree species and fungal strains $[6,11,16]$.

The critical attack or inoculation density threshold has been shown to vary according to the aggressiveness of the beetle and the pathogenicity of the fungus strain [33, 14]. It is also modulated by the health status and vigour of the trees, increasing with tree vigour and productivity (expressed as the ratio of the width of the latest increment ring to the sapwood section $[3,16,22]$ ) and changes during the season [1]. 
Decline and ultimately death of the trees is the usual indication that the critical threshold has been reached. But death of attacked or mass inoculated trees usually occurs several months after the aggression. It is therefore more convenient to use indices able to detect whether or not the fungus or the insect has been able to overcome the tree resistance. The length of the reaction zones around inoculation points has sometimes been considered as a possible indicator of resistance [13, 22], but its significance has been questioned as it displays only small variations in response to changing tree-health conditions or with increasing inoculation densities [10, 14].

Induced reaction zones occur both in the phloem and the sapwood in response to bark inoculation. They may therefore, together with the development of the fungus, have a negative impact on the water conducting ability of the sapwood, and result in impaired hydraulic functions of the tree [29]. There may be several causes of such impairment. The mechanical occlusion of tracheids by resin macromolecules or by mycelial strains in vicinity of the attack points may be one of them. In addition, air seeding into tracheids and cavitation [35] probably occurs before tracheid occlusion. Cavitation may be favoured by the presence of the fungal mycelium in the sapwood, but the precise chain of events reaching from mycelial spread into the sapwood to the irreversible loss of hydraulic conductivity is still poorly understood.

There may be several techniques to assess the amount of sapwood dysfunction. Staining dyes have been frequently used to evidence functional (stained) sapwood zones $[11,13,17,32]$. Losses of hydraulic conductivity can also be measured directly in cut stem segments using pressurised water and measuring the resulting flow through the stem $[10,34]$. Such direct measurements of losses of hydraulic conductivity in response to mass inoculations with increasing attack or inoculation densities could therefore be an efficient method to obtain an early marker of successful invasion and tree decline.

We investigated the characteristics of Scots pine responses to attacks by Ips acuminatus (Gyll.) and its associated fungus Ophiostoma brunneo-ciliatum (Math.). More than $95 \%$ of the insects of this species carry the fungus within mycangia on the external mandibular membrane [4, 24]. I. acuminatus preferentially attacks tree segments with thin bark. It has been responsible for damages that were locally very severe in the pine forests of central and South Eastern France [21]. In this study, we compared the threshold attack density derived from observations following natural attacks in a stand in Southern France, and the critical threshold of inoculation density, obtained experimentally on young trees in central France. Inoculation at varying densities were made on young trees, and sterile inoculations were performed in parallel in order to separate effects induced by wounding alone from pathogenic effects of the fungus.

\section{MATERIAL AND METHODS}

\subsection{Natural attacks}

The observations were made during March 1989, at Comps-sur-Artuby (Var, South-Eastern France), on 48 fifteen-year-old Scots pine trees (height: $8.2 \pm 0.05 \mathrm{~m}$; circumference at breast height: $44 \pm 0.3 \mathrm{~cm}$, i.e., ca. $14 \mathrm{~cm} \mathrm{DBH})$. They were naturally attacked by Ips acuminatus (Gyll.). Two 50-cm-long stem segments were collected on each tree, one in the upper third, and one in the middle of the trunk. The number of individual galleries (successfull attacks) and of aborted attacks was recorded on each segment, and related to the health status of the tree (still living or dead). Two of the trees presented only half of the stem length still living and a large blue staining; they were counted as dead. One had only the upper third declining, and was counted as still alive. No other intermediate cases were recorded.

\subsection{Mass inoculations}

During spring 1997, 220, 7 to 8-year-old Scots pine trees (Pinus sylvestris L.) were selected in a natural regeneration in the Forest of Rambouillet (Central France; height: 1 to $2.7 \mathrm{~m}$; dbh: $2-2.5 \mathrm{~cm}$ ). Inoculation was made with a 3-week-old monospore culture of Ophiostoma brunneo-ciliatum (Math.) isolated from I. acuminatus galleries on bait stems distributed in the pine forests of south-eastern France. Trees were inoculated in situ between June 28 and July 71997 with inoculation point densities ranging from 170 to $1270 \mathrm{~m}^{-2}$, on a belt width comprised between 16 and $52 \mathrm{~cm}$ (figure 1). Inoculations were made either with sterile malt agar disks, or with fungus cultures. Five-mm-diameter disks of bark were punched out down to the cambium. A disk of fungal culture or sterile malt-agar was inserted in the hole, bringing the mycelium in contact with the cambial layer. The hole was sealed again with the removed bark disk.

The impact of the inoculations was estimated 3 months later through records of:

- the length of induced reaction zones in the bark tissues;

- the sectional area of blue stained, dried or resin impregnated sapwood;

- the loss of hydraulic conductivity in the inoculated stem segments. 


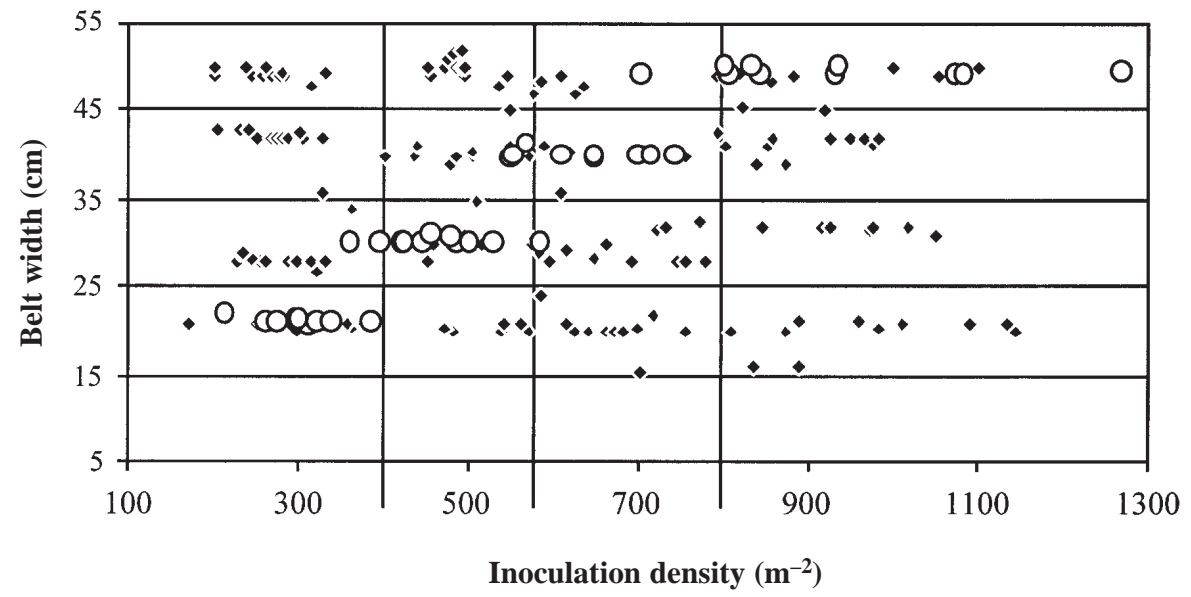

Figure 1. Density of inoculations with malt-agar sterile disks or cultures of Ophiostoma brunneo-ciliatum on young Scots pines. The actual densities are displayed as a function of the width of the inoculation belt. As a result of the lack of impact of the belt width, all statistical treatments were conducted using 4 inoculation density classes (as displayed by their limits: 400, $580,800)$ with similar numbers of trees. $\bigcirc$ : sterile agar; $\diamond$ : agar with fungus.
Twelve control trees, free of any inoculation or wounding, were harvested to estimate the maximal hydraulic conductivity. The inoculated trees (sterile or with fungus) were randomly divided into 2 equivalent groups. The trees in the first one were used for induced reaction zone and sapwood measurements, and those in the second one were used for hydraulic conductivity assessment.

Ten induced reaction zones were randomly selected, excluding the ones close to the border of the inoculation belts, and their length was recorded. Three stem sections were cut in each tree within the inoculated belt. Dried, resin soaked and blue stained areas were redrawn on transparent paper. Resulting drawings were digitised to estimate the area of each type of sapwood, with an image analysis software. The fraction of functional sapwood $\left(A_{\mathrm{s} \%}\right)$ was derived from these estimates.

The technique developed by Sperry et al. [34] was used to estimate the actual local hydraulic conductivity of $20 \mathrm{~cm}$ long stem segments that were cut from within the inoculation belt. Deionised, degassed and acidified water was used at a pressure of $5 \mathrm{kPa}$ obtained from a water tank placed exactly $0.5 \mathrm{~m}$ above the sample, and the flow through the segment was recorded as the weighted amount of water recovered at the open end of the segment after 10 min circulation. Hydraulic conductivity $(K)$ was calculated as:

$$
K=\frac{F \times L}{P}
$$

where $F$ is the flow of water $\left(\mathrm{kg} \mathrm{s}^{-1}\right), L$, the length of the segment (usually close to $0.2 \mathrm{~m}$ ) and $P$ the pressure applied at segment entry $(=\rho \mathrm{g} h$, with $h$, height of the water tank above the segment). Values of $K$ were standardised to sapwood specific hydraulic conductivity
$\left(K_{\mathrm{s}}, \mathrm{kg} \mathrm{m}^{-1} \mathrm{~s}^{-1} \mathrm{MPa}^{-1}\right)$ using the total sapwood cross sectional area of the sample.

The loss of conductivity is usually expressed with respect to maximal conductivity measured after resaturating xylem vessels under a high pressure $(0.175 \mathrm{MPa}$; [34]). In our case, due to the potential occurrence of tracheid occlusion, we estimated maximal conductivity from the relationship between diameter and actual conductivity obtained on the 12 healthy trees (figure 2). This relationship was later used to compute the maximal hydraulic conductivity of inoculated trees.

\subsection{Statistical analyses}

Due to the small diameter of the trees, it was not possible to obtain inoculation densities matching exactly the target values. Real densities were therefore recomputed for each tree (figure 1), leading to a continuum of values that were discretised into 4 groups with homogenous numbers of trees.

Normalised variance analyses were made using the GLM procedure of SAS (SAS Institute, Cary, NC), followed by Scheffe's t-test (or LSD when $n<5$ ), at a significance level of 0.05 . Graphical displays present mean values \pm confidence interval $(p=0.05)$.

\section{RESULTS}

\subsection{Natural attacks}

Records of natural attacks by the bark beetle Ips acuminatus resulted in the death of 26 among the 


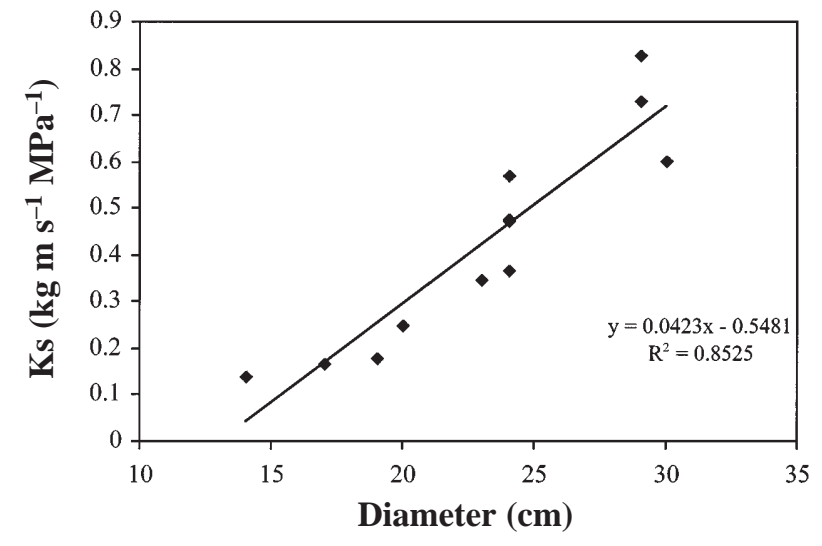

Figure 2. Relationship between sapwood cross-sectional area and hydraulic conductivity as recorded in the stems of 12 young Scots pine trees free of inoculations and wounding. The displayed linear regression was used as a calibration curve for the computation of maximal sapwood-specific hydraulic conductivity in inoculated trees.

48 selected trees. A very large difference of attack density was recorded between surviving (around $180 \pm 20$ attacks $\left.\mathrm{m}^{-2}\right)$ and dead trees $\left(1060 \pm 30\right.$ attacks $\left.^{-2}\right)$. The densities on dead trees ranged from 400 up to $1800 \mathrm{~m}^{-2}$. The trees were discretised into 9 equal attack-density classes $(0-200 ; 201-400 ; \ldots$.$) and the relative fraction of$ dead trees was computed in each class, and represented as a function of attack density (figure 3). A sigmoid relationship could be fitted to the data, with following equation:

$$
\text { Mortality }(\%)=\frac{1}{1+\left(\frac{D}{D_{50}}\right)^{\alpha}} \times 100
$$

with $D$ : density $\left(\mathrm{m}^{-2}\right)$ and $D_{50}$, density at which half the trees were killed. The adjusted relationship yielded a value of $D_{50}$ of about $510 . D_{95}$ (95\% killed trees) was close to 850: this value can be regarded as the mean critical attack density threshold of the stand.

\subsection{Mass inoculations}

A general ANOVA was conducted to test for the effects of three factors (presence or absence of the fungus in the malt agar disk, inoculation density and inoculation belt width) on four parameters (sapwood specific hydraulic conductivity, $K_{\mathrm{s}}$, length of the induced reaction zones in the phloem, fraction of resin soaked, of dry, and of healthy sapwood, table I). The inoculation with fungal strains yielded significant effects with respect to sterile malt-agar disks, on all measured parameters (with the exception of dry sapwood). Inoculation density had significant impacts on all parameters, while the width of the inoculation belt had none. We therefore skipped the factor "belt width" from all further analyses and concentrated on inoculation densities solely.

Sterile inoculations yielded $20 \mathrm{~mm}$ long reaction zones (average value), which length decreased only slightly to $12 \mathrm{~mm}$ at higher inoculation densities (figure $4 a$ ). The length of the induced reaction zones was very stable when the fungus was used, with no visible impact of density. The occurrence of such small differences in reaction zone lengths between sterile and fungal inoculations confirmed the weak pathogenic power of O. brunneo-ciliatum, and the non-specific nature of the induced reaction in the phloem.

Reactions in the sapwood were different. Sterile inoculations resulted in a small but stable reduction of healthy sapwood independently of density (figure $4 b$ ).

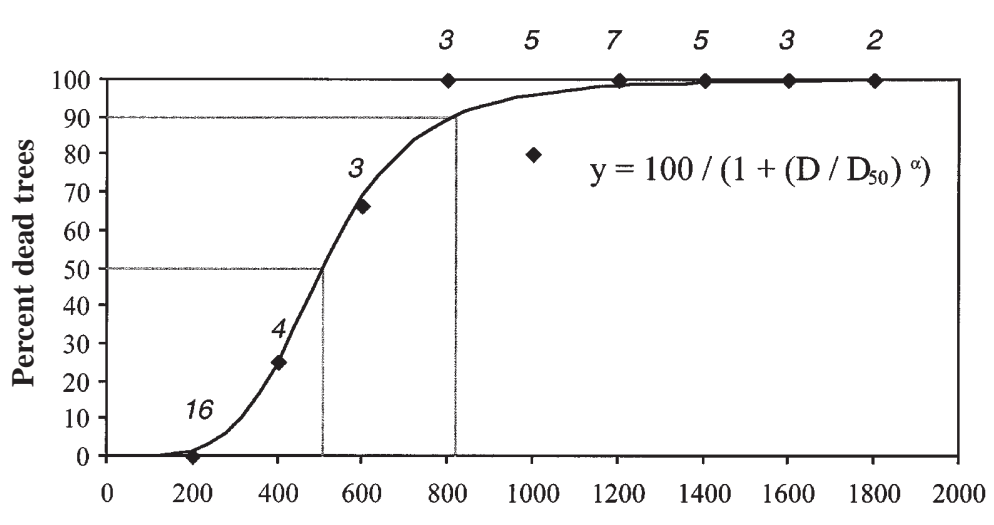

Attack densities $\left(\mathbf{m}^{-2}\right)$
Figure 3. Fraction of dead Scots pine trees $(\bullet)$ in a stand as a function of natural attack densities by Ips acuminatus. Trees were grouped into 10 equivalent attack-density classes. A logistic function (-) was fit to the data, and enabled to define a $D_{90}$ (density at which $90 \%$ of the trees died from the attacks). Total number of sampled trees: 48. The number of trees in each class is indicated. Value of parameters: $D_{50}=510$ (density at which $50 \%$ of the trees died); $\alpha=-4.69$. 
The loss, that never exceeded $10 \%$, was due to resin soaking (20\% of the loss, figure $4 c)$ and to tissue drying ( $80 \%$ of the loss) in close vicinity of the wounds. The presence of the fungus led to much more severe effects on sapwood. One of the trees inoculated at $1100 \mathrm{~m}^{-2}$ dis- played blue-staining, and had correspondingly only $40 \%$ healthy sapwood cross section left. No other tree presented blue staining. Loss of healthy sapwood increased significantly with inoculation densities (from 15 to almost $30 \%$ ). The contribution of resin soaking to this

Table I. Mass inoculation of young Scots pines with Ophiostoma brunneo-ciliatum: Results of a general ANOVA testing for the effects of the inoculation with fungal cultures, of the density of inoculation points and of the width of inoculation belts on different parameters describing the responses of the trees.

\begin{tabular}{lcccc}
\hline$P($ at $5 \%)$ & Inoculation & Density & Belt width & Interaction \\
\hline Hydraulic conductivity of inoculated stem segments $\left(K_{\mathrm{s}}\right)$ & 0.0001 & 0.0001 & 0.3267 & 0.1832 \\
Reaction length in the phloem & 0.0001 & 0.0579 & 0.5054 & 0.0064 \\
Resin soaked sapwood & 0.0001 & 0.0001 & 0.0670 & 0.3445 \\
Dry sapwood & 0.9881 & 0.0016 & 0.3372 & 0.7319 \\
Healthy sapwood & 0.0001 & 0.0001 & 0.1014 & 0.0129 \\
\hline
\end{tabular}

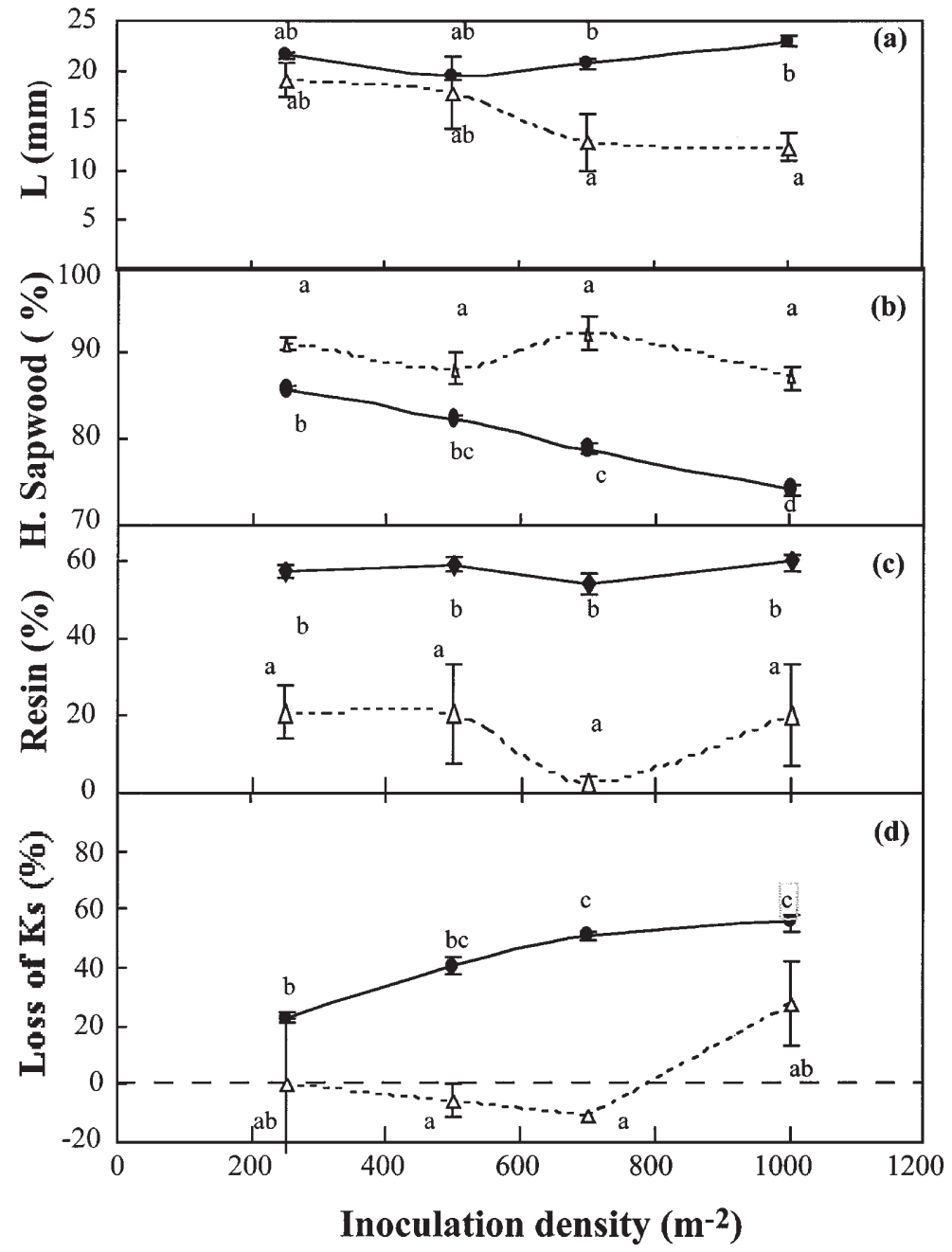

Figure 4. Impact of the density of inoculations with Ophiostoma brunneo-ciliatum into bark of young Scots pine trees on: (a) the length of the induced reaction zones in the bark tissues; (b) the fraction of sapwood remaining functional after inoculation; (c) the fraction of the impaired sapwood affected by resinosis and (d) the loss of hydraulic conductivity. $--\Delta--$ inoculation with sterile malt-agar; - - inoculation with fungal cultures. Means \pm confidence intervals; different letters indicate significant differences among the 8 means of a given data set $(p=0.05)$. 
loss represented $60 \%$, and was independent of inoculation density (figure 4c).

Sterile inoculations induced no significant loss of conductivity; the slight increase at highest density was not statistically significant. Inoculations with the fungus resulted in significant losses ranging from around $25 \%$ at lowest densities up to $55 \%$ at the highest ones (figure $4 d$ ); the impact of increasing inoculation densities was significant although small.

The fraction of intact sapwood cross-sectional area was significantly correlated with the loss of conductivity, with a non-linear relationship between the two parameters. The loss of conductivity increased much faster than the loss of intact sapwood (figure 5).

\section{DISCUSSION}

Our results with either records of natural attacks of young Scots pines by the bark beetle Ips acuminatus Gyll. or with mass inoculations of its associated fungus Ophiostoma brunneo-ciliatum Math. into the bark confirmed the weak aggressiveness of this bark beetle-fungus association. The natural attacks allowed us to estimate the critical attack density threshold at around $850 \mathrm{~m}^{-2}$ (95\% dead trees above this density). For the fungus, inoculations close to $1000 \mathrm{~m}^{-2}$ induced significant damage to the sapwood of the infected trees (but not necessarily death).

A comparison with the few published data on critical threshold densities of attacks or inoculations (table II) yielded the following observations: 1 . There is an agree-

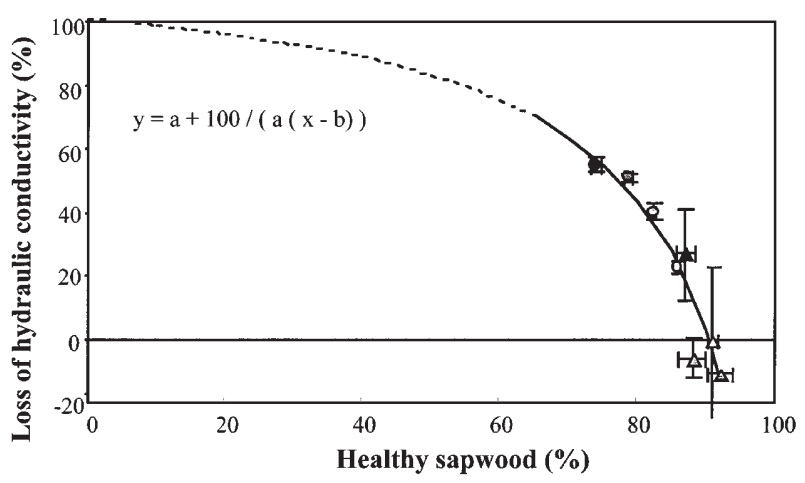

Figure 5. Relationship between visually assessed damage in the sapwood, and the measured loss of hydraulic conductivity, in stem segments of young Scots pines mass-inoculated with Ophiostoma brunneo-ciliatum ( $\bigcirc$ to $\bigcirc$ ) and with sterile malt$\operatorname{agar}(\Delta)$. Parameters: $\mathrm{a}=120 ; \mathrm{b}=109 ; \alpha=0.044$. ment between the two techniques: mass inoculation of the associated fungus or direct attacks by the bark beetle result usually in close values despite the known differences in the frequency of association between fungi and insects (high in I. acuminatus; much lower in the other species); 2. The association I. acuminatus - O. brunneociliatum is one of the less pathogenic ones when compared to others, either on different host species, or even for Scots pine.

The different markers of susceptibility of the trees to the fungus behaved very dissimilarly in response to increasing inoculation densities. The length of the induced reaction zone in the bark tissues has been frequently proposed as an index for the resistance of trees towards attacks $[13,14,22]$. It is expected that, below the threshold inoculation density, long reactions indicate a low efficiency of the resistance mechanisms. Above the threshold, the length of the reactions may be reduced due to a lack of available carbohydrates needed to accumulate secondary compounds. In addition, this length has been shown to vary with season and with tree vigour [22]. A long reaction zone is expected to reveal an aggressive fungal strain [13]. In the case of O. brunneociliatum, the length was close to $20 \mathrm{~mm}$, that is much lower than those recorded after inoculation with other fungi (see table III). Moreover, it was only slightly different from that of reactions induced by wounding alone (sterile inoculations). This confirms that the induced reaction is rather unspecific, and that the presence of the fungus is not increasing its intensity to a significant degree. The lack of difference in this parameter with increasing densities up to the threshold density observed for natural attacks agrees with earlier results $[9,11]$ and strengthens the conclusion that reaction zone length in bark tissues is a poor index for tree resistance [14].

Damage in the sapwood could be another relevant criterion for tree resistance, even if it may be argued that this damage occurs late in the infection cycle, and plays probably only a minor role in the potential success of insect installation. The latter is probably strongly relying on the dynamic balance between rapid responses of trees, and velocity of fungus propagation in the phloem.

Nevertheless, our results demonstrated clearly that sapwood damage was a more sensitive indicator than reaction zone length. Even if this damage remained rather low when compared to that recorded in similar trees inoculated with $L$. wingfieldii at $400 \mathrm{~m}^{-2}$ [10], it nevertheless displayed a significant increase with density, and differed largely from that induced by wounding alone. The latter resulted mainly in a very limited sapwood drying very close to the wounds and almost no resinosis. The presence of the fungus resulted in heavy resinosis, sapwood drying and in one case, blue staining. 
Table II. A synthesis of published values of critical density thresholds obtained with natural attacks by the insect, or by mass-inoculation with the associated fungus.

\begin{tabular}{|c|c|c|c|c|c|}
\hline Tree species & Insect species & Critical density $\left(\mathrm{m}^{-2}\right)$ & Associated fungus & Critical density $\left(\mathrm{m}^{-2}\right)$ & Author \\
\hline Picea abies & Ips typographus & $300-500$ & Ceratocystis polonica & 400 & [5] \\
\hline Pinus sylvestris & Tomicus piniperda & 400 & & & [16] \\
\hline Pinus sylvestris & (Tomicus piniperda) & & Leptographium wingfieldii & 400 & [11] \\
\hline Pinus sylvestris & (Tomicus piniperda) & & Ophiostoma minus & 800 & [33] \\
\hline Pinus sylvestris & Ips acuminatus & 850 & Ophiostoma brunneo-ciliatum & $>1000$ & this work \\
\hline Pinus ponderosa & Dendroctonus ponderosae & 60 & & & {$[31]$} \\
\hline
\end{tabular}

Table III. Published values for the length of the induced reaction zone following isolated- or mass-inoculation of bark beetle-associated fungi into the bark of diverse tree species.

\begin{tabular}{|c|c|c|c|c|c|}
\hline Fungus & Tree species & $\begin{array}{l}\text { Reaction zone } \\
\text { length }\end{array}$ & $\begin{array}{c}\text { Fraction damaged } \\
\text { sapwood }\end{array}$ & $\begin{array}{l}\text { Inoculation } \\
\text { density }\end{array}$ & Reference \\
\hline Ceratocystis polonica & Picea abies & $40-65 \mathrm{~mm}$ & $53-78 \%$ & 400 & [13] \\
\hline Ophiostoma piceae & Picea abies & $10-13.5 \mathrm{~mm}$ & $16 \%$ & 400 & [13] \\
\hline Leptographium wingfieldii & Pinus sylvestris & $85-100 \mathrm{~mm}$ & $15-70 \%$ & 400 & [11] \\
\hline Leptographium wingfieldii & Pinus sylvestris & $100-400 \mathrm{~mm}$ & & & [27] \\
\hline Leptographium wingfieldii & Pinus sylvestris & $>82 \mathrm{~mm}$ & all & 300 & [17] \\
\hline Ophiostoma brunneo-ciliatum & Pinus sylvestris & $15-50 \mathrm{~mm}$ & & Single inoculations & [26] \\
\hline Ophiostoma brunneo-ciliatum & Pinus sylvestris & $20-25 \mathrm{~mm}$ & $25 \%$ & $>1000$ & this work \\
\hline Ophiostoma minus & Pinus sylvestris & $>36 \mathrm{~mm}$ & all & 300 & [17] \\
\hline
\end{tabular}

In contrast, the loss of hydraulic conductivity demonstrated even larger dysfunctions in the sapwood than those derived from direct visual observations. Up to $60 \%$ loss of conductivity was recorded at the highest densities. This was still largely below the amount of damage caused by $L$. wingfieldii [10], confirming again a weak pathogenicity of $O$. brunneo-ciliatum.

What could be the impact of such hydraulic impairment on the water relations of the whole tree? Hydraulic properties were measured on small segments cut within the inoculation belt which may explain why against expectations, belt width had no impact on the measured loss of conductivity. The loss of conductance at whole trunk level was probably more affected by the extent of inoculation or attacks along the stem, but we have no direct measurement to support this point.

Nevertheless, to discuss the impact on water relations at whole tree level, one needs to take into account the relative importance of resistances along the soil-toneedle water pathway. It may be safely assumed that the distribution of resistances to water flow is approximately $40 \%$ in the extra fascicular pathway in the needles, $10 \%$ in the shoot xylem, $10 \%$ in the root xylem and again $40 \%$ in the root cortex (Cochard, personal communication). A rough calculation shows that a $50 \%$ increase of resistance in the sapwood would only result in a $5 \%$ increase in total resistance, which is almost undetectable with classical techniques like combined records of transpiration and needle water potential.

The most striking result was the significant but nonlinear relationship between the amount of damage and the loss of conductivity; the latter increasing much faster then the former. Loss of hydraulic functionality was clearly due to the presence of the fungus, as wounding at similar densities induced almost no loss. This discrepancy between anatomical observations and recorded loss of hydraulic conductivity may imply several explanations:

- a rapid spread of the fungus in the sapwood without any visible anatomical damage and an embolisation of the tracheids that can only be detected by conductivity measurements;

- the induction of cavitation and embolism at some distance from the fungal mycelia. It has sometimes been hypothesised that micro-organisms (or induced reactions) could emit secondary metabolites able to decrease the surface tension of xylem sap, and therefore increase the vulnerability to cavitation. This hypothesis was put forward for the pine wilt nematode [15] and for bark-beetles [12], but is far from being demonstrated; 
- the mere fact that anatomical damage is assessed on 2D wood sections, while hydraulic impairment is recorded on 3D stem segments. The impact of a given amount of visible damage could change dramatically depending on the spatial distribution of the lesions; in our case, inoculation points from successive inoculation rings were not aligned, but overlapping, and this distribution probably maximised the conductivity losses induced by a given extent of cross sectional damage.

Detailed microscopic studies combined with conductance measurement of whole stems would be required to answer these questions related to the interplay between fungal development in the sapwood and induced hydraulic dysfunctions.

Can we conclude from these observations that the critical threshold of inoculation density was reached in this experiment? The experiment did not last long enough to observe tree death. The indirect indices used to characterise the impact of inoculations (amount of damage in the sapwood from anatomical and hydraulic points of view) increased gradually in response to increasing inoculation densities and did not display the expected threshold type response (fungus contained in the reaction zones and low densities, and fungal spread to the whole tree at densities above the threshold). Could this lead to a contrasted tree survival with death occurring after several months only at the highest densities? This question still remains open, and would need many more informations on the complex interplay between fungal colonisation, impairment of watertransport and tree decline. Nevertheless, it is clear from these experiment, that the amount of damage in the sapwood displays a larger variability in response to increasing inoculation densities than the ones in the bark.

\section{CONCLUSION}

The mutualistic association Ips acuminatus/Ophiostoma brunneo-ciliatum displayed only a weak pathogenicity towards young Scots pines, as revealed from the observed critical threshold of natural attack densities in pine stands $\left(850 \mathrm{~m}^{-2}\right)$, and from the limited extent of damage induced by controlled inoculations of the fungus into the bark. The extent of damage in the sapwood nevertheless displayed a significant increase with increasing inoculation densities while the length of reaction zones in the bark did not. This observations again confirms that the latter is only a poor index of tree defence ability against fungal attacks. The highest inoculation densities $\left(1000 \mathrm{~m}^{-2}\right)$ promoted visible damage in the sapwood and large losses of hydraulic conductivity. No threshold response was visible from these observations. Furthermore, we were unable to predict whether the inoculated trees would have died after a few months or recovered from the damage. The question of the critical threshold inoculation density still remains open.

Acknowledgments: This work was supported by the European Union Project "Stress and Tree Health" (FAIR 3 CT96-1854), and by a grant of the Région Centre to N.G. The authors are grateful to "Office National des Forêts" for providing the Scots pine stand in the forest of Rambouillet, and to P. Romary and J. Garcia for their technical help. Helpful comments by two anonymous reviewers are gratefully acknowledged.

\section{REFERENCES}

[1] Baier P., Defence reactions of Norway spruce (Picea abies Karst) to controlled attacks of Ips typographus (L.) (Col., Scolytidae) in relation to tree parameters, J. Appl. Entomol. 120 (1996) 587-593.

[2] Berryman A.A., Resistance of conifers to invasion by bark beetle-fungus associations, BioScience, 22 (1972) 598-602.

[3] Berryman A.A., Population dynamics of bark beetles, in: Mitton J.B., Sturgeon K.B. (Eds.), Bark beetles in North American conifers, Austin, 1982, pp. 264-314.

[4] Berryman A.A., Adaptative pathways in scolytid-fungus associations, in: Wilding N., Collins N.M., Hammond P.M., Webber J.F. (Ed.), Insect-fungus interactions, 14th Symp. Roy. Entomol. Soc. London, 1988, pp. 145-159.

[5] Christiansen E., Ceratocystis polonica inoculated in Norway spruce: blue-staining in relation to inoculum density, resinosis and tree growth, Eur. J. For. Pathol. 15 (1985) 160-167.

[6] Christiansen E., Ips / Ceratocystis-infection of Norway spruce: what is a deadly dosage?, Z. Ang. Entomol. 99 (1985) 6-11.

[7] Christiansen E., Horntvedt R., Combined Ips / Ceratocystis attack on Norway spruce and defensive mechanisms of the trees, Z. Ang. Entomol. 96 (1983) 110-118.

[8] Christiansen E., Waring R.H., Berryman A.A., Resistance of conifers to bark-beetle attack: searching for general relationships, For. Ecol. Manage. 22 (1987) 89-106.

[9] Croisé L., Dreyer E., Lieutier F., Effects of drought stress and severe pruning on the reaction zone induced by single inoculations with bark beetle associated fungus (Ophiostoma ips) in the phloem of young Scots pines, Can. J. For. Res. 28 (1998) 1814-1824.

[10] Croisé L., Lieutier F., Cochard H., Dreyer E., Drought, high density inoculation with Leptographium wingfieldii, and hydraulic functions of young Scots pine (Submitted).

[11] Croisé L., Lieutier F., Dreyer E., Scots pine responses to number and density of inoculation points with 
Leptographium wingfieldii Morelet, a bark beetle-associated fungus, Ann. Sci. For. 55 (1998) 497-506.

[12] Hobson K.R., Parmenter J.R., Wood D.L., The role of fungi vectored by Dendroctonus brevicomis Leconte (Coleoptera: Scolytidae) in occlusion of ponderosa pine xylem, Can. Entomol. 126 (1994) 277-282.

[13] Krokene P., Solheim H., Pathogenicity of four bluestain fungi associated with aggressive and non-aggressive bark beetles, Phytopathology, 88 (1998) 39-44.

[14] Krokene P., Solheim H., What do low-density inoculations with fungus tell us about fungal virulence and tree resistance?, in: Lieutier F., Mattson W.J., Wagner M.R. (Ed.), Physiology and genetics of tree-phytophage interactions, Gujan (France), 31/08-05/09 1997, INRA Paris, 1999, pp. 353-362.

[15] Kuroda K., Mechanism of cavitation development in the pine wilt disease, Eur. J. For. Pathol. 21 (1991) 82-89.

[16] Långström B., Hellqvist C., Ericsson A., Gref R., Induced defense reaction in Scots pine following stem attacks by Tomicus piniperda, Ecography 15 (1992) 318-327.

[17] Långström B., Solheim H., Hellqvist C., Gref R., Effects of pruning young Scots pines on host vigor and susceptibility to Leptographium wingfieldii and Ophiostoma minus, two blue-stain fungi associated with Tomicus piniperda, Eur. J. For. Pathol. 23 (1993) 400-415.

[18] Legrand Ph., Les attaques de Scolyte acuminé sur Pin sylvestre en Auvergne de 1988 à 1994, Rev. Sc. Nat. d'Auvergne 60 (1996) 45-57.

[19] Lieutier F., Les réactions de défense des conifères et stratégies d'attaque de quelques Scolytides européens, Mém. Soc. R. Belge Entomol. 35 (1992) 529-539.

[20] Lieutier F., Les scolytes des conifères : importance de l'hôte, Phytoma - La Défense des végétaux, 463 (1994) 15-19.

[21] Lieutier F., Faure T., Garcia J., Les attaques de scolytes et le dépérissement du Pin sylvestre dans la région ProvenceCôte-d'Azur, Rev. Forest. Française XL (1988) 224-232.

[22] Lieutier F., Garcia J., Romary P., Yart A., Jactel H., Sauvard D., Inter-tree variability in the induced defense reaction of Scots pine to single inoculations by Ophiostoma brunneo-ciliatum, a bark beetle-associated fungus, For. Ecol. Man. 59 (1993) 257-270.

[23] Lieutier F., Garcia J., Yart A., Romary P., Wound reactions of Scots pine (Pinus sylvestris L.) to attacks by Tomicus piniperda L. and Ips sexdentatus Boern. (Col., Scolytidae), J. Appl. Entomol. 119 (1995) 591-600.

[24] Lieutier F., Garcia J., Yart A., Vouland G., Pettinetti M., Morelet M., Ophiostomales (Ascomycètes) associées à Ips acuminatus Gyll (Coleoptera: Scolytidae) sur le Pin sylvestre (Pinus sylvestris L) dans le Sud-Est de la France et comparaison avec Ips sexdentatus Boern, Agronomie 11 (1991) 807-817.
[25] Lieutier F., Géri C., Goussard F., Rousseau G., Problèmes entomologiques actuels du Pin sylvestre en région centre, La Forêt Privée 155 (1984) 25-36.

[26] Lieutier F., Sauvard D., Brignolas F., Picron V., Yart A., Bastien C., Jay-Allemand C., Changes in phenolic metabolites of Scots pine phloem induced by Ophiostoma brunneo-ciliatum, a bark beetle-associated fungus, Eur. J. For. Pathol. 26 (1996) 145-158.

[27] Lieutier F., Yart A., Garcia J., Poupinel B., Lévieux J., Do fungi influence the establishment of bark beetles in Scots pine? in: Mattson W.J., Lévieux J., Bernard-Dagan C. (Eds.), Mechanism of woody plant defenses against insects: search for pattern, 1988, pp. 321-334.

[28] Mulock P., Christiansen E., The threshold of successful attack by Ips typographus on Picea abies: a field experiment, For. Ecol. Man. 14 (1986) 125-132.

[29] Paine T.D., Raffa K.F., Harrington T.C., Interactions among scolytid bark beetles, their associated fungi, and live host conifers, Ann. Rev. Entomol. 42 (1997) 179-206.

[30] Raffa K.F., The mountain pine beetle in Western North America, in: Berryman A.A. (Ed.), Dynamics of forest insect populations, Plenum Press, New-York and London, 1988, pp. 505-530.

[31] Raffa K.F., Berryman A.A., The role of host plant resistance in the colonization behavior and ecology of bark beetles (Coleoptera: Scolytidae), Ecol. Monogr. 53 (1983) 27-49.

[32] Reid R.W., Whitney H.S., Watson J.A., Reactions of the Lodgepole pine to attack by Dendroctonus ponderosae Hopkins and blue stain fungi, Can. J. Bot. 45 (1967) 1115-1125.

[33] Solheim H., Långström B., Hellqvist C., Pathogenicity of the blue-stain fungi Leptographium wingfieldii and Ophiostoma minus to Scots pine: effect of the tree pruning and inoculum density, Can. J. For. Res. 23 (1993) 1438-1443.

[34] Sperry J.S., Donnelly J.R., Tyree M.T., Seasonal occurrence of xylem embolism in sugar maple (Acer saccharum), Am. J. Bot. 78 (1988) 1212-1218.

[35] Tyree M.T., Sperry J.S., Vulnerability of xylem to cavitation and embolism, Annu. Rev. Plant Phys. Mol. Bio. 40 (1989) 19-38.

[36] Waring R.H., Pitman G.B., Physiological stress in lodgepole pine as a precursor for mountain pine beetle attack, Z. Ang. Entomol. 96 (1983) 265-270.

[37] Wong B.L., Berryman A.A., Host resistance to the fir engraver beetle. 3: lesion development and containment of infection by resistant Abies grandis inoculated with Trichosporium symbioticum, Can. J. Bot. 55 (1977) 2358-2365. 